\title{
Features of the Organization of Work of Public Affairs Divisions of The Ministry of Defence of Ukraine During the Armed Aggression of The Russian Federation Against Ukraine
}

\section{Introduction}

Purpose of the article is a detailed analysis of the gradual development of mechanisms of implementation of state information policy by the Ministry of Defence of Ukraine while countering hybrid aggression in 2014-2019, as well as development of further recommendations for reform of the abovementioned direction.

In 2014, in violation of all principles of the international law, the Russian Federation carried out an armed aggression and annexed the Crimean Peninsula, as well as part of the territories belonging to sovereign Ukraine. An analysis of the events that had taken place, as well

$1 \mathrm{PhD}$ in Public Administration, Postdoctoral Student Educational and Research Centre for Strategic Communications in the Sphere of National Security and Defence of the National Defence University of Ukraine named after Ivan Cherniakhovskyi, mou-infopress@ukr.net, https://orcid.org/0000-0002-0805-4092.

2 Postgraduate Student Educational and Research Centre for Strategic Communications in the Sphere of National Security and Defence of the National Defence University of Ukraine named after Ivan Cherniakhovskyi, olexsii.chernobai@gmail.com, https://orcid. org/0000-001-9970-5534. 
as numerous current studies, show that the Russian Federation has implemented a prepared plan to destabilize the situation in Ukraine. The hybrid component of aggressor's actions was characterized by wellplanned and prepared information campaigns against Ukraine, including its leadership, security and defence forces, which were involved in protecting the country's territorial integrity, in order to discredit them at the international arena and within the country. Establishing a system to counter information attacks by the Russian Federation in 2014 was one of the priority tasks, and the main actors to implement them was the Ministry of Defence of Ukraine. The result of this work was the establishment of a strategic communications system in the defence sector of Ukraine, taking into account the experience of leading countries. Further development and improvement of mechanisms of work and implementation of strategic communications is an extremely necessary issue and an important indicator in the process of strengthening the information security of the state.

A significant contribution to the development of theoretical and practical substantiation of mechanisms of using strategic communications was the researches of such Ukrainian scientists as V. Lipkan, D. Dubov, V. Petrov, Y. Radkovets, O. Salnikova, S. Antonenko, A. Barovska, T. Bezverkhniuk, O. Valevskyi, O. Voitko, and others. However, the relevance and issues of the topic of the material require further research in this area.

In this article, the authors aim to analyze the unique experience in organizing a system of work to combat information threats from the Russian Federation in 2014-2019, in the context of experience in developing a strategic communications system in the security and defence sector of Ukraine.

The relevance of the study of the chosen topic is determined by the need to comply with the interests of national security of Ukraine and effective measures in the field of strategic communications in the Security Service of Ukraine in the Russian Federation propaganda and dissemination of false information about Ukraine through media and social networks.

The priority ways to achieve strategic goals are the formation and capacity building of security and defence forces in the field of strate- 
gic communications as part of a nationwide and interagency system of strategic communications aimed at supporting policy formulation and implementation in the Security Service of Ukraine and achieving national defence goals.

In addition, in accordance with NATO's requirements for the development of information and communication sphere, all processes should be simplified and accelerated so that information and communication aspects in the security and defence spheres become the basis of all levels of policy making and planning of strategic communications in Ukraine.

The purpose of the research is scientific and theoretical substantiation of the system of strategic communications in the Security Service of Ukraine and development of scientific and practical recommendations to public and military authorities aimed at improving the use of strategic communications in the Security Service of Ukraine in the context of the National Security Strategy of Ukraine. Doctrine of Ukraine, Strategic Defence Bulletin of Ukraine, and Doctrine of Information Security of Ukraine.

The study is based on the principles and main categories of dialectical knowledge of social phenomena and processes, as well as systemic, inductive, deductive, functional and other theoretical (philosophical, general scientific) and specific scientific methods. The research used such general scientific methods as description, analysis and personal observation of the implementation of processes of the organization of work of Public Affairs Divisions of the Ministry of Defence of Ukraine during the armed aggression of the Russian Federation against Ukraine and theoretical - generalization and systematization - during the review of forms and methods of work of divisions in the specified period of time.

To achieve the goal of research and solving the tasks, a set of general scientific methods was used, which allowed to systematize empirical information, analyze the current state of formation and implementation of the system of strategic communications in the security and defence sector of Ukraine.

The novelty of the study is that from the standpoint of a systematic approach considered public administration aspects of the complex problem of using strategic communications in general and theoretical and methodological foundations for the development of strategic com- 
munications in the security and defence sector of Ukraine in particular, virtually none.

\section{Analysis of situation in Ukraine in 2014}

The hybrid aggression of the Russian Federation, beginning with the annexation of Crimea and the gradual occupation of Donetsk and Luhansk regions in 2014 , was accompanied by massive information campaigns against Ukraine by the aggressor state.

The hybrid component of the conflict has been tracked since its inception. Information-psychological war, humiliation of Ukrainian Ianguage and culture, falsification of Ukrainian history, formation of an alternative to reality distorted information picture of the world by the Russian media was identified as one of the current threats to Ukraine's national security. ${ }^{3}$

The main narratives of the Kremlin's propaganda machine were established against Ukraine's defence forces, which at the time were resisting Russia's regular troops and the Kremlin-controlled armed terrorist groups.

Russia's occupation of Donbas is part of a "hybrid" war against Ukraine that has begun in February 2014 with the illegal annexation of Crimea. At the same time, Kremlin's expansion in the "Ukrainian direction" should be seen in the context of Russia's general neo-imperial aggressive policy on a world stage. The conflict in the East of Ukraine, according to the UN, "is one of the deadliest in Europe since the World War II". As of the end of 2019, 13,000 people have died in Donbas, 28,000 were injured, and about 1.8 million residents of Donbass and Crimea became internally displaced. ${ }^{4}$

Constant attacks of the aggressor state, streams of lies, fakes, manipulation of facts at the highest level in 2014 forced the executive authori-

3 Pro rishennia Rady natsionalnoi bezpeky i oborony Ukrainy "Pro Stratehiiu natsionalnoi bezpeky Ukrainy" \#287/2015 vid 6 travnia 2015 roku. https://zakon.rada.gov.ua/ laws/show/287/2015\#Text [In Ukrainian].

4 Material "Radio Svoboda": "OON porakhuvala zhertvy boiovykh dii na Donbasi sered tsyvilnykh i kombatantiv". https://www.radiosvoboda.org/a/oon-zvit-ghertvy-donbas/30272212.html [In Ukrainian]. 
ties to reconsider the specifics and mode of operation of public affairs (PA) units and accumulate efforts of all communication units of security and defence agencies in a single direction. At that time, the situation in Ukraine was characterized by a certain public confusion. Interagency coordination was just beginning to be established after the Revolution of Dignity: there was a certain rotation and reappointment of responsible persons, and the journalistic community adapted to new realities. New heads of state authorities were appointed, new teams were being formed, which will be responsible for the implementation of information policy in the future. In 2014, PA units of security and defence agencies were not ready to fully resist hybrid attacks. One of the main challenges were insufficient technical support, lack of experience in working with foreign media, lack of experience in combat operations; lack of a perfect system of accreditation of journalists. In the early stages, there was a difficulty in understanding of the top military leadership about the need for systematic work with Ukrainian and foreign journalists. These problems had to be solved manually; the systemic work was established only a year later.

\section{Coordination of security and defence representatives}

With the beginning of intensive hostilities in the East of Ukraine, as a result of coordinated cooperation of representatives of the security and defence sector, it was decided to establish the first joint press center in the combat area to inform the population of Ukraine and international community about events in Ukraine. Representatives of the PA units of the Ministry of Defence, the National Guard, the Ministry of Internal Affairs, the Border Guard Service and others took part in the work of the joint press center. It was at this time that a media pool of Ukrainian journalists was formed, covering events in the combat area and regularly visiting the line of contact. In 2014, the number of journalists who worked daily in the Anti-Terrorist Operation (ATO) area reached 50-70 people, which complicated the work of the joint press center. There was a significant workload on the press center in the form of round-the-clock informing of journalists, hourly broadcasts on live television, work on rebuffing fakes and holding briefings for Ukrainian and foreign media. 
With the beginning of active hostilities in the East of Ukraine and the interest of journalists in covering these events, the question arose of the proper organization of accreditation of Ukrainian and foreign journalists.

This required a number of administrative procedures. This procedure was introduced in January 2015 and involved an accreditation from the Security Service of Ukraine as well as a press card to perform an editorial task at the Ministry of Defence of Ukraine.

\section{Creation of procedure of first accreditation}

Accreditation was and remains legally mandatory and is carried out in accordance with the Instruction on the procedure for admission of journalists, media representatives to the facilities of the Ministry of Defence of Ukraine and the Armed Forces of Ukraine. ${ }^{5}$

In 2015, this procedure involved submitting an application to the Security Service of Ukraine for accreditation, signed by an authorized media person, no later than ten working days before the scheduled visit, reviewing the application within one working day and providing a response. Upon successful completion of accreditation, journalist received the right to travel to the combat area, where upon arrival he provided the Ukrainian military at the checkpoint with a journalist's ID of the relevant media, passed the accreditation test, in case of accreditation, received confirmation or refusal depending on the current security situation in the combat area.

From January 2015, the leadership of the Ministry of Defence of Ukraine introduced the issue of special press cards for the editorial task in the East of Ukraine. A press card was a personalized document certifying the rights of a media to perform editorial tasks in the ATO area, as well as in deployment areas of military units of the Armed Forces and / or their subordinate units. The procedure for obtaining such a card was provided by the Instruction of the Ministry of Defence of Ukraine "On

5 Nakaz Ministra oborony Ukrainy "Pro zatverdzhennia Instruktsii pro poriadok dopusku zhurnalistiv, pratsivnykiv zasobiv masovoi informatsii na obiekty Ministerstva oborony Ukrainy ta Zbroinykh Syl Ukrainy" \# 399 vid 14.06.2012 (iz zminamy). https:// zakon.rada.gov.ua/laws/show/z1149-12\#Text [In Ukrainian]. P. 1-2. 
the procedure for issuing and using press cards by media representatives to cover the activities of the Armed Forces of Ukraine in the ATO area". ${ }^{6}$ Accreditation of media representatives in the ATO area/ Joint Forces Operation (JFO) area (since 2018), has been carried out by the Press Center of the Operation Headquarters. To get to combat areas, civilian journalists of domestic and foreign media sent a list of documents to the Press Center. For representatives of Ukrainian media (citizens of Ukraine) the term of accreditation was no more than seven days, foreign journalists - no more than 30 days, which was due to the additional verification conducted by the Security Service of Ukraine. A two-tier system of accreditation of journalists was established. Press card of the second degree of accreditation (blue) - was a personalized document certifying permission of a media to perform editorial tasks in the JFO area in Donetsk and Luhansk regions, as well as in deployment areas of military units of the Armed Forces of Ukraine or their subordinate units. The press card of the second level of accreditation did not give the journalist the right to work on the line of contact. The press card of the ATO and the JFO of the first degree of accreditation (green) was issued to journalists after a special course at the Ministry of Defence of Ukraine and gave the right to perform editorial tasks directly on the frontline, as well as in other deployment areas of military units of the Armed Forces of Ukraine.

During the special course, media representatives got acquainted with the structure of the Armed Forces, functions and tasks of the security and defence sector of Ukraine, the legal framework of the Armed Forces, military terminology, the interaction of media representatives with PA officers within the JFO, and participated in practical classes on tactical medicine, rules for handling explosives and rules of conduct for media representatives in the combat area. The validity of both press cards was 6 months. A representative of the press center was informed about the issue of the appropriate level of accreditation of journalists. Further, the media visited the areas of the operation in close cooperation with military information structures in Donetsk and Luhansk regions.

In 2014, with the beginning of the ATO, the issues of utmost imporatance were to inform about current security situation, as well as

6 Poriadok oformlennia pres-kart predstavnykamy ZMI shchodo vysvitlennia diialnosti Obiednanykh syl. https://www.mil.gov.ua/dlya-zmi/ato-press.html [In Ukrainian]. 
counter information warfare waged against our country by the Russian Federation. Hundreds of representatives of television channels, news agencies and print media went to the East of Ukraine at that time, as the topic of "war" induced the greatest interest from society and the international community. In those rather difficult times for the establishment of a system of informing the public, the Russian Federation, in addition to committing armed aggression, conducted information warfare and generated dozens of fakes. The Ministry of Defence constantly received inquiries from journalists, but neither the Armed Forces of Ukraine nor the media fully knew how to counter this amount of misinformation. At that time, the Armed Forces of Ukraine did not have an extensive system of PA units and press centers, and there were no positions of Public Affairs officers (PAO) in the units. Most commanders refused to comment to civilian journalists because they did not have skills or authority. The sources of information were civilian experts, volunteers or soldiers, middle-ranking officers, who had no information about the general situation, so information appeared in the information space which did not always objectively reflected the general picture. Lack of official information often gave rise to speculation, gossip and negative public reaction.

\section{Press Center of ATO Headquarters}

Assessing the importance of the information component in the area of hostilities, in May 2014 it was decided to include forces and means of ATO of a separate unit to work with the media - the Press Center of the ATO Headquarters, established to implement the President's order "On public information about the Anti-Terrorist Operation."7 At the same time, the positions of PAOs of the sectors were introduced, of which there were four at that time. Representatives of the PA Office of the Ministry of Defence and military media were sent to the ATO Headquarters and sectors to perform tasks. The Press Center of the ATO Headquarters was tasked with systematically, fully and reliably informing the

7 Rozporiadzhennia Prezydenta Ukrainy "Pro zakhody shchodo zabezpechennia informuvannia hromadskosti pro antyterorystychnu operatsiiu" \#862/2014-rp, vid 15.05.2014. https://zakon.rada.gov.ua/laws/show/862/2014-\%D1\%80\%D0\%BF\#Text [In Ukrainian]. P 1, par. 3. 
public about the progress of the ATO, providing assistance to journalists, media workers in their professional activities, promptly providing them with information on the fight against terrorism in the ATO, as well as assistance in the processing and transmission of such information. ${ }^{8}$

For the prompt collection of information on enemy's shelling of peaceful settlements, photo and video recording of criminal activities of the Russian occupation troops, coverage of the Armed Forces of Ukraine, including civil-military cooperation, groups of military journalists, photographers and videographers started to work on a rotating basis in the ATO area since April 2016. The mobile press groups were equipped with appropriate audiovisual and automotive equipment. The rotation period of such groups was one month. The JFO Press Center held daily briefings and press conferences on the security situation in the operation area, organized and conducted information events with the participation of the JFO Commander, as well as provided information on the work of the OSCE Special Monitoring Mission.

The information prepared by the JFO Press Center was posted on the official website of the Ministry of Defence of Ukraine, on social media, and disseminated through media outlets. Videos made by the "Military TV of Ukraine", prepared by military correspondents in the JFO area were and are used by Ukrainian central and foreign TV channels. Every day, the JFO Press Center supports the activity of civilian journalists in the JFO area, with an average of up to 70 correspondent groups of domestic and foreign media per month. Thus, this system has worked satisfactorily and now effectively informs the public about the activities of the Armed Forces of Ukraine, provides working conditions for military and civilian media in the JFO area.

\section{First special course for Ukrainian journalists}

A separate important aspect of the organization of work with journalists in 2016 is courses at the Ivan Cherniakhovskyi National Defence University of Ukraine. Representatives of central and regional TV channels,

8 Zakon Ukrainy "Pro borodbu z teroryzmom" \#638-IV, vid 03.07.2020. https:// zakon.rada.gov.ua/laws/show/638-15\#Text [In Ukrainian]. 
print media, news agencies and Internet publications of Ukraine were involved to such courses.

The event was organized by the Ministry of Defence of Ukraine, the Ministry of Information Policy, the National Security and Defence Council of Ukraine and the Ivan Chernyakhovskyi National Defence University of Ukraine.

The program included a theoretical course to study the structure, functions and tasks of the security and defence sector of Ukraine, the legal framework of the Armed Forces of Ukraine, military terminology, the procedure of interaction of civilian media with officers of the ATO press structures, as well as practical classes on tactical medicine, rules for handling explosives and rules of conduct for media representatives in the combat area.

In order to deepen the cooperation between military and civilian journalists, the course included briefings with the invitation of media representatives, media experts and press officers.

This is the first time such an event has been held for representatives of the civilian media in the Armed Forces of Ukraine. The main purpose of the courses was to improve the procedure for admission of civilian media representatives to military facilities in the combat area, to improve the procedure for journalists to perform editorial tasks, save the lives and health of service personnel and media representatives during dangerous editorial tasks in the combat area, prevention of leakage of sensitive information.

The course is held in several sessions: the first - at the National Defence University of Ukraine (theoretical course), the second - practical classes on the basis of one of the training centers of the Ukrainian Army.

One of the objectives of the courses was to introduce two-level accreditation for the work of representatives of the civilian media in the ATO area.

Journalists wishing to be accredited to the frontline had to undergo a three-day training. One day was devoted to training in the field (on the range), the rest of the time was devoted to mastering theoretical and practical knowledge: how to work in the combat area, how to protect yourself during shelling, acquaintance with the legal framework of the agency. 
In 2015, given the importance of implementing the leading foreign experience, the Ministry of Defence of Ukraine introduced the project "EMBEDDED JOURNALIST", during which foreign journalists were attached to the military unit, could be on the fronline for a long time. Among the journalists who visited the combat area at the time were representatives of all the world's top-ranked media outlets.

\section{Review of Defence Ministry PA}

In 2014, the Ministry of Defence of Ukraine had the following military media: the Central Printing Bodies "People's Army" and the "Army of Ukraine", the printing bodies "Wings of Ukraine" and the "Navy of Ukraine", as well as the Central TV and Radio Studio "Breeze" of the Ministry of Defence Ukraine, which actually implemented the work of PA subdivisions of the Armed Forces of Ukraine, because at that time there were no relevant units in the Armed Forces of Ukraine.

The Doctrine of Information Security assigned certain tasks to the Ministry of Defence of Ukraine, implementation of which was entrusted to the military media of the Ministry of Defence of Ukraine, including organization of relations with Ukrainian and foreign media to cover the situation in the ATO area in Donetsk and Luhansk regions; support by information means of performance of tasks of defence of Ukraine; providing reliable information to service members of the Armed Forces of Ukraine, other military agencies, in particular through the media of the Armed Forces of Ukraine. ${ }^{9}$

In order to improve the work of military media in 2014-2019, the Ministry of Defence of Ukraine implemented measures to reform subordinate media structures.

In accordance with the Law of Ukraine "On Reforming State and Municipal Print Media"10 and the joint directive of the Ministry of Defence

9 Pro rishennia Rady natsionalnoi bezpeky i oborony Ukrainy "Pro Doktrynu informatsiinoi bezpeky Ukrainy» \#47/2017 vid 29 hrudnia 2016 roku. https://zakon. rada.gov. ua/laws/show/47/2017\#Text [In Ukrainian]. P. 6.

10 Zakon Ukrainy "Pro reformuvannia derzhavnykh i komunalnykh drukovanykh zasobiv masovoi informatsii" \#917-VIII, vid 24.12.2015. https://zakon.rada.gov.ua/laws/ show/917-19/ed20151224\#Text [In Ukrainian]. P. 1-4. 
of Ukraine and the General Staff of the Armed Forces of Ukraine, in 2018 the Ministry of Defence of Ukraine carried out measures to reform the printing units of the Ministry of Defence.

In accordance with the Law of Ukraine "On Information Agencies"11 and the Law of Ukraine "On Central Executive Bodies"12, the Information Agency of the Ministry of Defence of Ukraine was established, which became the legal successor of the Printed media of the Ministry of Defence of Ukraine. The news agency is officially registered with the Ministry of Justice of Ukraine as a full-fledged state news agency.

\section{Establishment of MOD Information Agency}

The establishment of the Information Agency took into account the experience of the military media during the armed conflict in the East of Ukraine. In 2019, the Information Agency submitted documents for the registration of the trademark "Armylnform".

The Information Agency is designed to collect, process, create, store, prepare for the dissemination, release and dissemination of official information, as well as information products on the activities of the Ministry of Defence and the Armed Forces of Ukraine.

The main tasks of the Information Agency are to participate in the implementation of the state information policy in the Ministry of Defence and the Armed Forces of Ukraine, primarily to counter the destructive information influence of the Russian Federation during its hybrid war; collection, processing, storage, preparation and delivery of reliable information to service members of the Armed Forces of Ukraine, information support of the Ministry of Defence and the Armed Forces of Ukraine, editorial and publishing activities; creation and distribution of image and advertising products about the activities of the Ministry of Defence and the Armed Forces of Ukraine; participation in interaction with mass media.

11 Zakon Ukrainy "Pro informatsiini ahentstva". \#74/95-VR, vid 16.07.2019. https:// zakon.rada.gov.ua/laws/show/74/95-\%D0\%B2\%D1\%80\#Text [In Ukrainian]. P. 1.

12 Zakon Ukrainy "Pro tsentralni orhany vykonavchoi vlady" \#917-VIII, vid 15.06.2017. https://zakon.rada.gov.ua/laws/show/3166-17\#Text [In Ukrainian]. Par. 6. 
In accordance with the assigned tasks, the Information Agency is able to progressively join the work during crisis situations, as well as, if necessary, to integrate into the forces and means of the defence forces in order to perform the tasks assigned to them.

\section{StratCom Coordination and Monitoring Office}

In 2016, the Ministry of Defence of Ukraine created a new unit - the Strategic Communications Coordination and Monitoring Office, the main task of which was to coordinate and control the implementation of strategic communications in the Ministry of Defence of Ukraine and the Armed Forces of Ukraine. ${ }^{13}$

In 2016, the Ministry of Defence of Ukraine developed the Concept of Strategic Communications of the Ministry of Defence of Ukraine and the General Staff of the Armed Forces of Ukraine, which defines a set of modern views, goals, principles and activities of the Ministry of Defence of Ukraine on establishment and implementation of strategic communications in the Armed Forces of Ukraine. ${ }^{14}$ During creation of the document, the best practices of the world's leading countries were studied and propositions of foreign strategic communications advisers, in particular from the United States of America, were taken into account.

In March 2016, in cooperation with the NGO "Spirit of America" and American institutions, the project of the first military radio "Army FM" was implemented. Currently, Army FM is a radio station that systematically informs the Armed Forces of Ukraine and civil society about the situation in the combat area, about the life of the Ukrainian army and other important events in the security and defence sector of Ukraine. The military radio coverage network covers the territory along the contact line in the east of the country, on the border with the occupied

13 Nakaz Ministerstva oborony Ukrainy "Pro zatverdzhennia Polozhennia pro Viddil koordynatsii stratehichnykh komunikatsii ta monitorynhu" \#317 vid 12.06.2017. URL: https://www.mil.gov.ua/content/mou_orders/317_nm_2017.pdf [In Ukrainian]. P. 1.

14 Kontseptsiia stratehichnykh komunikatsii Ministerstva oborony Ukrainy ta Zbroinykh Syl Ukrainy: zatverdzheno Nakazom Ministerstva oborony Ukrainy vid 22.11.17 No 612. http://www.mil.gov.ua/content/mou_orders/612_nm_2017.pdf [In Ukrainian]. P. 1, 2, 3. 
Crimea, as well as in the vast majority of large cities throughout Ukraine, including the capital Kyiv.

In 2017, on the basis of the Ivan Chernyakhavskyi National Defence University of Ukraine, the Training and Research Center for Strategic Communications in the Field of National Security and Defence was established, the main tasks of which are - methodical support of the process of preparation, conducting research on strategic communications and international cooperation with similar specific research institutions. $^{15}$

\section{Conclusions}

Analysis of the activities of communication units of the Ministry of Defence of Ukraine shows the effectiveness of work on the establishment and improvement of mechanisms for implementing state information policy by the Ministry of Defence of Ukraine in combating hybrid aggression in 2014-2019. However, this work needs constant development and improvement, taking into account current realities, new challenges and threats. This experience is ingenious and unique because it was formed and adapted in the context of countering hybrid aggression within military conflict in modern Europe. The study of this experience can be used in the training strategic communications specialists, as well as in the establishment of modern information policy in the strategic communications field.

Summing up the results of research and analysis, we can say that the study of this topic should be continued in order to study individual positions and situations to prevent mistakes and searching the algorithms for dealing with complex crises that can arise in the security and defence sector in the future.

\section{Bibliography}

Kontseptsiia stratehichnykh komunikatsii Ministerstva oborony Ukrainy ta Zbroinykh Syl Ukrainy: zatverdzheno Nakazom Ministerstva oboro-

15 Nakaz nachalnyka Natsionalnoho universytetu oborony Ukrainy imeni Ivana Cherniakhovskoho \#88, vid 29 kvitnia 2020 roku [In Ukrainian]. P.1. 
ny Ukrainy [The Concept of Strategic Communications of the Ministry of Defense and the Armed Forces of Ukraine, approved by the Order of the Ministry of Defense of Ukraine] 22.11.17 no. 612 Retrieved from http://www.mil.gov.ua/content/mou_orders/612_nm_2017.pdf [In Ukrainian] pp. 1, 2, 3.

Material "Radio Svoboda": "OON porakhuvala zhertvy boiovykh dii na Donbasi sered tsyvilnykh i kombatantiv" ["Radio Europe" article: "UN has counted combat casualties in Donbas among combatants and civilians"] Retrieved from: https://www.radiosvoboda.org/a/oon-zvitghertvy-donbas/30272212.html [In Ukrainian].

Nakaz Ministra oborony Ukrainy "Pro zatverdzhennia Instruktsii pro poriadok dopusku zhurnalistiv, pratsivnykiv zasobiv masovoi informatsii na obiekty Ministerstva oborony Ukrainy ta Zbroinykh Syl Ukrainy" [The Order of the Minister of Defense of Ukraine "On Approval of the Instruction on the Procedure for Admission of Journalists and Media Representatives to the Facilities of the Ministry of Defense of Ukraine and the Armed Forces of Ukraine"] no 399 from 14.06.2012 Retrieved from: https://zakon.rada.gov.ua/laws/show/z1149-12 pp.1-2.

Nakaz Ministerstva oborony Ukrainy "Pro zatverdzhennia Polozhennia pro Viddil koordynatsii stratehichnykh komunikatsii ta monitorynhu" [The Order of the Ministry of Defense of Ukraine "On authorization of the Provision about Strategic Communications and Monitoring Office"] no. 317 from 12.06.2017 Retrieved from: https://www.mil.gov. ua/content/mou_orders/317_nm_2017.pdf [In Ukrainian] pp.1-2.

Nakaz nachalnyka Natsionalnoho universytetu oborony Ukrainy imeni Ivana Cherniakhovskoho [The Order of the Chief of the Ivan Cherniakhovskyi National Defence University of Ukraine] no. 88, from 29.05. 2020 pp. 1-2.

Poriadok oformlennia pres-kart predstavnykamy ZMI shchodo vysvitlennia diialnosti Obiednanykh syl [The procedure for issuing press cards for media representatives to cover the activities of the Joint Forces] Retrieved from https://www.mil.gov.ua/dlya-zmi/ato-press.html

Pro rishennia Rady natsionalnoi bezpeky i oborony Ukrainy "Pro Doktrynu informatsiinoi bezpeky Ukrainy» [The Decision of the National Security and Defense Council of Ukraine «On the Doctrine of Infor- 
mation Security of Ukraine»] no. 47/2017 from 29.12.2016 Retrieved from: https://zakon. rada.gov.ua/laws/show/47/2017 pp. 6.

Pro rishennia Rady natsionalnoi bezpeky i oborony Ukrainy "Pro Stratehiiu natsionalnoi bezpeky Ukrainy" [The Decision of the Security and Defense Council of Ukraine "On National Security Strategy of Ukraine"] no. 287/2015 from 6.05.2015 Retrieved from: https://zakon.rada.gov.ua/laws/show/287/2015

Rozporiadzhennia Prezydenta Ukrainy "Pro zakhody shchodo zabezpechennia informuvannia hromadskosti pro antyterorystychnu operatsiiu" [The Order of the President of Ukraine "On measures to ensure public awareness of the anti-terrorist operation"] no. 862/2014-rp, from 15.05.2014 Retrieved from: https://zakon.rada.gov.ua/laws/ show/862/2014-\%D1\%80\%D0\%BF pp 1-3.

Zakon Ukrainy "Pro borodbu z teroryzmom" [The Law of Ukraine "On countering terrorism"] no 638-IV, from 03.07.2020 Retrieved from: https://zakon.rada.gov.ua/laws/show/638-15

Zakon Ukrainy "Pro informatsiini ahentstva" [The Law of Ukraine "On Information Agencies"] no. 74/95-VR, from 16.07.2019 Retrieved from: https://zakon.rada.gov.ua/laws/show/74/95-\%D pp. 1

Zakon Ukrainy "Pro tsentralni orhany vykonavchoi vlady" [The Law of Ukraine "On Central Executive Bodies"] no. 917-VIII, from 15.06.2017 Retrieved from: https://zakon.rada.gov.ua/laws/ show/3166-17 p. 6

Zakon Ukrainy "Pro reformuvannia derzhavnykh i komunalnykh drukovanykh zasobiv masovoi informatsii" [The Order of the Ministry of Defense of Ukraine "On authorization of the Provision about Strategic Communications and Monitoring Office"] no 917-VIII, from 24.12.2015 Retrieved from: https://zakon.rada.gov.ua/laws/ show/917-19/ed2015122 pp 1-4.

\section{Summary}

Hybrid aggression of the Russian Federation, starting from the illegal annexation of Crimean peninsula and consistent occupation of the territory of Donetsk and Luhansk regions in 2014, was accompanied by massive information campaigns against Ukraine from the aggressor state. 
Hybrid component of the conflict was observable since the inception. Information-psychological warfare, humiliation of Ukrainian language and culture, falsification of Ukrainian history, establishment of alternative reality of the distorted information picture of the world by the Russian media were identified as one of the most relevant threats to the national security of Ukraine. Current challenges and threats to the national security of Ukraine determine the overall necessity of finding a viable, adequate, as well as integrated tool, which will make possible to establish consistent cooperation in the security and defence sector. Qualitative analysis of the organization of work of units of the Ministry of Defence of Ukraine during the armed aggression of the Russian Federation against Ukraine in order to develop new effective mechanisms of countering the aggression is of upmost importance.

Development of this work on the basis of the unique experience will give the chance to establish effective resistance to destructive information campaigns which are conducted by the external aggressor.

Keywords: hybrid aggression, interdepartmental coordination, public relations, information, strategic communications 